Article

\title{
Targeting of the Essential acpP, ftsZ, and rne Genes in Carbapenem-Resistant Acinetobacter baumannii by Antisense PNA Precision Antibacterials
}

\author{
Alireza Japoni Nejad ${ }^{1,2}\left(\mathbb{D}\right.$, Nader Shahrokhi $^{2}(\mathbb{D})$ and Peter E. Nielsen ${ }^{1, *(D)}$ \\ 1 Center for Peptide-Based Antibiotics, Department of Cellular and Molecular Medicine, Faculty of Health and \\ Medical Sciences, The Panum Institute, University of Copenhagen Blegdamsvej 3, \\ DK-2200 Copenhagen, Denmark; alireza@sund.ku.dk \\ 2 Department of Molecular Biology, Pasteur Institute of Iran, Pasteur Ave, Tehran 13164, Iran; \\ Shahrokhi@pasteur.ac.ir \\ * Correspondence: ptrn@sund.ku.dk
}

Citation: Nejad, A.J.; Shahrokhi, N.; Nielsen, P.E. Targeting of the

Essential acpP, ftsZ, and rne Genes in Carbapenem-Resistant Acinetobacter baumannii by Antisense PNA Precision Antibacterials. Biomedicines 2021, 9, 429. https://doi.org/ 10.3390/biomedicines 9040429

Academic Editor: William D. Lubell

Received: 17 March 2021

Accepted: 8 April 2021

Published: 15 April 2021

Publisher's Note: MDPI stays neutral with regard to jurisdictional claims in published maps and institutional affiliations.

Copyright: (c) 2021 by the authors. Licensee MDPI, Basel, Switzerland. This article is an open access article distributed under the terms and conditions of the Creative Commons Attribution (CC BY) license (https:// creativecommons.org/licenses/by/ $4.0 /)$.
Abstract: Infections by carbapenem-resistant A. baumannii (CRAB), a widespread nosocomial pathogen, are becoming increasingly difficult to prevent and treat. Therefore, there is an urgent need for discovery of novel antibiotics against CRAB. Programmable, precision antisense antibiotics, e.g., based on the nucleic acid mimic PNA (peptide nucleic acid) have shown promise in this respect in the form of PNA-BPP (bacteria penetrating peptide) conjugates targeting essential bacterial genes. In the present study, we designed and synthesized a series of PNA-BPPs targeting the translation initiation region of the $f t s Z, a c p P$, or rne gene of CRAB strains. The antimicrobial activity of the compounds and effects on gene expression level was compared to that of analogous mismatch PNA controls. Three antisense conjugates (KFF) ${ }_{3} \mathrm{~K}-\mathrm{eg} 1-(a c p P) P N A(5639)$, (KFF) ${ }_{3} \mathrm{~K}-\mathrm{eg} 1-(f t s Z) P N A(5612)$, and (KFF) $3_{3}$ K-eg1-(rne)PNA (5656) exhibited complete growth inhibition against several CRAB strains at 1-2, $2-8$, and $2 \mu \mathrm{M}$, respectively, and the compounds were bactericidal at $1-2 \times$ MIC. The bactericidal effect was correlated to reduction of target gene mRNA level using RT-qPCR, and the compounds showed no bacterial membrane disruption activity at 1-2× MIC. PNA5612 was tested against a series of $12 \mathrm{CRAB}$ isolates and all were sensitive at 2-8 $\mu \mathrm{M}$. In addition, the conjugates exhibited no cellular toxicity in the HepG2 cell line (up to $20 \mu \mathrm{M}$ ) and did not shown significant antibacterial activity against other Gram negatives (E. coli, P. aeruginosa). These results provide a starting point for discovery of antisense precision designer antibiotics for specific treatment of CRAB infections.

Keywords: precision antibiotics; antisense; A. baumannii; carbapenem resistance; peptide nucleic acid (PNA)

\section{Introduction}

Acinetobacter baumannii is a major cause of both community-associated and nosocomial infections that are difficult to control and treat worldwide, and antibiotic resistance is becoming a major problem in hospitals where outbreaks are reported frequently, especially in intensive care units $[1,2]$. A baumannii has a remarkable ability to rapidly develop antibiotic resistance, which has led to multidrug resistant strains within a few decades [3]. Presently, a substantial proportion of these isolates are also carbapenem resistant, and the mortality rates for the most common carbapenem resistant A. baumannii (CRAB) infections, primarily hospital-acquired pneumonia and bloodstream infections, can approach 60\% [4]. Currently used antimicrobials for CRAB (polymyxins and tigecycline) are far from perfect therapeutic options due to toxicity issues and increasing resistance rates also against these antibiotics [3,4]. Thus, discovery of new classes of antibiotics with novel molecular targets and mechanism of action for treating and managing CRAB infections is urgently needed.

Exploitation of antisense antimicrobials in the form of short oligonucleotide analogous and mimics that inhibit that expression of essential genes at the RNA level is a promising 
approach [5,6], which was introduced two decades ago using 9-12-mer PNA (peptide nucleic acid) oligomers targeting the essential $a c p P$ gene in E. coli [7]. Subsequently, PNA and PMO (phosphorodiamidate morpholino oligomer) antibacterial agents have been studied extensively for targeting a multitude of genes in many bacterial species [8,9]. In theory, this approach allows targeting of any expressed gene, thereby making it druggable, and circumventing known resistance mechanisms. In addition, the intended target bacteria can be programmed specifically via the chosen gene sequence with high precision.

PNA is a charge neutral, hydrophilic synthetic polymer with a pseudo-peptide backbone exhibiting high sequence specific affinity for complementary RNA (and DNA) molecules. In addition, PNA oligomers have very high biological stability being practically inert to both nucleases and peptidases [10], but cellular (including bacterial) uptake is a general challenge in the application of PNAs (as well as PMOs) as antisense agents. However, conjugation to bacteria penetrating peptides (BPPs) was discovered as a successful way to ensure increased PNA uptake and thereby efficacy [7]. In the last two decades, many mRNA encoding essential genes in clinically pathogenic bacteria have been validated as possible targets for antisense antibacterial agents. The most effective antisense agents were designed complementary to the mRNA around or proximally upstream of the translation start codon [11]. Upon binding to the mRNA, PMO and PNA act through steric hindrance of mRNA translation or processing, contrary to some other antisense oligonucleotides that induce mRNA degradation via activation of RNase $\mathrm{H}$.

In this study, we have investigated and characterized antisense specific antimicrobial activity of the series of peptide-PNA conjugates targeting the essential acpP, ftsZ, and rne genes in carbapenem resistant clinical Acinetobacter baumannii isolates with the ultimate aim of discovering new precision antibiotics.

\section{Materials and Methods}

\subsection{Bacterial Strains}

Strains used in this study are listed in Table S1-A. Clinical isolates of carbapenemresistant $A$. baumannii (CRAB) were previously collected from Valiasr hospital (ArakIran) [12]. Standard biochemical tests were performed to identify A. baumannii phenotypically. In addition, bla OXA-51 PCR was performed. Species-level identification of isolates was reconfirmed by the MALDI Biotyper system (Statens Seruminstitute (SSI), Copenhagen, Denmark). One CRAB strain (SSI1104) was kindly provided by Dr. Anette M. Hammerum (SSI carbapenemase collection, Copenhagen-Denmark). A. baumannii ATCC 19606 was used as a reference strain. Clinical isolates were previously tested for the presence of the carbapenemase encoding genes such as bla $a_{O X A-51}, b l a_{O X A-23}, b l a_{O X A-24}, b l a_{O X A-58}, b l a_{I M P}$, $b a_{V I M}, b l a_{S P M}, b l a_{G E S}, b l a_{S I M}$, and $b l a_{G I M}$ according to the Ellington study (Table S1B) [13].

\subsection{Antibiotic MIC}

All minimum inhibitory concentration (MIC) determinations for antibiotics were performed by the standard microdilution method in 96-well microplate (Thermo-Scientific, Roskilde, Denmark) or by gradient test strips (Liofilchem, Italy) according to the Clinical and Laboratory Standards Institute guidelines [14]. Escherichia coli ATCC 25922 was used as control.

\subsection{Computational Screening of Sequence Regions in the mRNA of Target Genes}

Acinetobacter baumannii strains that were examined for designing antisense in this study are shown in Table S2. Sequence alignment of target genes (obtained from GenBank database updated January 2019) were carried out using the Basic Local Alignment Search Tool (BLAST) on the National Center for Biotechnology Information (NCBI) website [15].

\subsection{BPP-PNA Synthesis}

Peptide-PNA conjugates (Tables S3-S5) were synthesized by continuous solid phase synthesis using Boc-chemistry as previously described [7]. The conjugates were purified 
by reversed phase high-performance liquid chromatography (HPLC) on an RP18 column using a $0-40 \%$ acetonitrile gradient in $0.1 \%$ trifluoroacetic acid. Characterization in terms of purity and identity was done by HPLC and matrix-assisted laser desorption/ionizationtime of flight (MALDI-TOF) mass spectrometric analyses. All conjugates exhibited masses within experimental error corresponding to the calculated mass and were $>95 \%$ pure by HPLC analysis (Figure S7).

\subsection{BPP-PNA MIC}

MIC values were determined by broth microdilution according to standard protocols with a few modifications. An overnight bacterial cell culture was diluted to approximately $5 \times 10^{5} \mathrm{CFU} / \mathrm{mL}$ in non-cation-adjusted Muller Hinton Broth (MHB). Then, $180 \mu \mathrm{L}$ bacterial solutions were dispensed into a low-bind 96-well plate (Thermo-Scientific, Roskilde, Denmark) along with $20 \mu \mathrm{L}$ of BPP-PNA compound (BPP-PNA was serially diluted 2-fold from 16 to $0.5 \mu \mathrm{M}$ in a 96-well plate). The plate was incubated in a Tecan Genios plate reader (GMI, Minnesota, Ramsey, USA) at $37{ }^{\circ} \mathrm{C}$ for $18 \mathrm{~h}$ with linear shaking, OD was measured every $20 \mathrm{~min}$ at $595 \mathrm{~nm}$. The MIC was determined as the lowest concentration, that inhibited visible growth $(\mathrm{OD}<0.1)$ in the wells [16]. The minimum bactericidal concentration (MBC) values were determined by plating $10 \mu \mathrm{L}$ samples from the wells with no visible turbidity onto Mueller-Hinton agar plates. The MBC is determined the lowest concentration of BPP-PNA that reduces the viability of the initial bacterial inoculum by $\geq 99.9 \%$ (3-log reduction in CFU / mL). A minimum of two independent experiments (biological replicates) of the assay were conducted, and two technical replicates were used in each experiment for each bacterium, compound, and concentration.

\subsection{Time-Kill Assay}

A. baumannii strains in logarithmic growth phase were diluted to $\sim 10^{6} \mathrm{CFU} / \mathrm{mL}$ and incubated with different concentration (corresponding to the MIC-value) of the BPP-PNA at $37^{\circ} \mathrm{C}$ for $6 \mathrm{~h}$.

Bacterial cultures were harvested at 0,90 min, 3 and $6 \mathrm{~h}$. The content of each well was added to $0.9 \mathrm{~mL}$ of $\mathrm{MHB}$ and centrifuged at $9300 \times g$ for $5 \mathrm{~min}$. Supernatants were removed and the cell pellets were suspended in fresh pre-warmed MHB $(100 \mu \mathrm{L})$. Tenfold serial dilution were prepared, and $10 \mu \mathrm{L}$ aliquots were plated on Mueller-Hinton agar and incubated overnight at $37^{\circ} \mathrm{C}$ to determine the $\mathrm{CFU} / \mathrm{mL}$ [17].

\subsection{HepG2 Cell Toxicity}

The cell toxicity of selected BPP-PNAs was determined using HepG2 hepatocytes grown in DMEM (low glucose) medium supplemented with $100 \mathrm{U} / \mathrm{mL}$ penicillin, $100 \mu \mathrm{g} / \mathrm{mL}$ streptomycin, 1\% glutamax, and 10\% fetal bovine serum (FBS) (Thermofisher Scientific, Roskilde, Denmark), at $37^{\circ} \mathrm{C}$ with $5 \% \mathrm{CO}_{2}$. Then, 7000-10,000 cells were seeded in each well of a 96-well plate. After $48 \mathrm{~h}$, the BPP-PNAs were added (six replicates for each concentration), followed by overnight incubation. Total amount of adenosine triphosphate (ATP) was used as a measure of cell viability, according to the CellTiter-Glo luminescent cell viability assay (Promega, Madison, WI, USA) kit. BPP-PNAs concentrations ranged from 2.5 to $20 \mu \mathrm{M}$. Potassium dichromate $(100 \mu \mathrm{M})$ was used as a positive control.

\subsection{Envelope Disruption}

A culture of A. baumannii ATCC 19606 was grown in MHB (195 rpm at $\left.37^{\circ} \mathrm{C}\right)$, until OD595 $=0.4$. Then, bacterial cells were pelleted by centrifugation, washed with $0.9 \% \mathrm{NaCl}$, and resuspended in MHB at an OD595 = 0.1. Sytox green dye (Invitrogen) was added to the bacterial culture at a concentration of $2 \mu \mathrm{M}$ followed by incubation for 5 min at $37^{\circ} \mathrm{C}$, followed by addition of the desired amount of BPP-PNA in a 96-well plate format. Fluorescence intensity $(\lambda \mathrm{ex}=480 \mathrm{~nm}, \lambda \mathrm{em}=520 \mathrm{~nm})$ was measured every $5 \mathrm{~min}$ for $90 \mathrm{~min}$ at $37^{\circ} \mathrm{C}$ with continuous shaking. Colistin (Sigma Aldrich, Merck, Darmstadt, Germany) at $1 \times$ and $2 \times$ MIC concentrations provided the positive control [18]. 


\subsection{Real-Time RT-PCR}

Real time RT-PCR was used to determine the relative expression level of the target gene upon treatment with match BPP-PNA compared to mismatch and untreated controls. The primers for q-PCR were designed to match conserved gene sequences using the AlleleID7 software (Premier Biosoft, San Francisco, CA, USA) (Table S6). Additionally, for more accurate expression of the genes at treatment and untreated conditions, the efficacy of target gene and internal controls primers was calculated by using three consecutive dilutions of the sample cDNA and drawing a standard curve through the slope of the line. NormFinder software was used to select the most stable reference gene among polA, zipA, and 16S rRNA. Statistical analysis was carried out on the gene expression levels normalized to the chosen reference gene (16S rRNA) through $-\Delta \mathrm{Ct}$ analysis. The relative expression of each gene was determined by the $2^{-\Delta \Delta C T}$ method [19]. We used the GenEx standard (NormFinder and GeNorm) software (bioMCC, Germany) for analyzing the data.

An overnight culture of bacteria was diluted 1:100 in MHB medium and was grown with shaking $(160 \mathrm{rpm})$ at $37^{\circ} \mathrm{C}$ to reach the OD595 $=0.2$. Then, the bacterial culture was treated with different concentrations of BPP-PNA for $1 \mathrm{~h}$ and the bacterial cells were harvested by centrifugation and the cell pellet used for RNA extraction [19].

Total RNA was isolated using the GeneJET RNA purification kit (ThermoFisher Scientific, Roskilde, Denmark) following the manufacturer's protocol. RNA samples were treated with DNase for $30 \mathrm{~min}$ at $37^{\circ} \mathrm{C}$ (Turbo DNA-free kit Ambion/Applied Biosystems, Carlsbad, CA, USA) and then incubated at $72{ }^{\circ} \mathrm{C}$ for $5 \mathrm{~min}$ to inactivate the DNase. The genomic DNA (gDNA) contamination was checked by polymerase chain reaction (PCR). RNA concentrations were determined by Nanodrop spectrophotometry at $260 \mathrm{~nm}$ and purity was checked by determining the absorption ratios at $260 / 280 \mathrm{~nm}$. Total RNA $(0.5 \mu \mathrm{g})$ was reverse-transcribed to yield cDNA as template for real-time quantitative PCR using the Quanti Tect reverse transcription kit (Qiagen, Copenhagen, Denmark). The cDNA was diluted 1:50 and used as a template in the reaction. The real-time polymerase chain reaction was carried out with $5 \mu \mathrm{L}$ of cDNA in a $20 \mu \mathrm{L}$ reaction consisting of $4 \mu \mathrm{L}$ Light Cycler Fast Start DNA Master SYBER I Green (Roche), $0.5 \mu \mathrm{L}$ of each primer (final concentration $=0.25 \mu \mathrm{M}$ ), and $10 \mu \mathrm{L}$ of water using Biorad CFX96 TouchTM real-time PCR detection system (Bio-Rad Laboratories Inc., Hercules, CA, USA) under these conditions: pre-incubation at $95{ }^{\circ} \mathrm{C}$ for $8 \mathrm{~min}$, followed by 40 cycles with denaturing at $95{ }^{\circ} \mathrm{C}$ for $10 \mathrm{~s}$, annealing at $50{ }^{\circ} \mathrm{C}$ for $15 \mathrm{~s}$, and elongation at $72{ }^{\circ} \mathrm{C}$ for $15 \mathrm{~s}$ and then 8 min final extension.

\subsection{Statistics}

All statistical analyses were carried out in SPSS 17.0 (SPSS, Chicago, IL, USA). Data are expressed as mean \pm standard deviation (SD) of the biological replicates and analyzed using Student's $t$-test and ANOVA. $p$ values of $\leq 0.05$ were considered significant.

\section{Results}

\subsection{PNA Design for the mRNA of Target Genes}

\subsubsection{AcpP}

The $a c p P$ gene is the original and to date most frequently used antibacterial antisense target $[7,16,17,20-22]$. When searching the acpP gene in the NCBI (GenBank) and Genolist databases, two lengths for this gene in different strains of $A$. baumannii were discovered (Figures S2 and S4). The acpP coding gene in A. baumannii ATCC19606, AYE, and SDF strains was $276 \mathrm{bp}$ in length, while the length was $237 \mathrm{bp}$ for both ACICU and ATCC17978 strains. The difference was related to 39 bases in the first part of the gene utilizing either of two translation initiation sites (GTG at +1 or +40 ). Therefore, we designed PNAs targeting both of these sites (Figure 1, Table 1). 


\section{$+1 \quad$ acpP AYE $\quad+\mathbf{6 0}$ GTGGCAAATCAAACGCCACAAGCAATGAGGAGAATTCCTGTGAGCGATATCGAACAACGC CACCGTTTAGT 5639 CACTCGCTATA 5652}

Figure 1. Sequence from the acpP mRNA and positions of the PNA targets.

Table 1. PNAs targeted to the acpP gene sequence of A. baumannii AYE are displayed with their designation numbers. The MIC values $(\mu \mathrm{M})$ for the four CRAB strains are presented compared to that for the standard, ATCC 19606 strain. m: Match, mm: Mismatch. * in Sigma MHB medium without cation. ${ }^{* *}$ in Oxoid MHB medium, cation adjusted. ${ }^{\text {a }}$ According to the start codon of the AYE, SDF strains. ${ }^{b}$ According to the start codon of the ACICU, ATCC17978 strains. The gene sequence obtained from GenBank database updated January 2019. ${ }^{\mathrm{c}} \mathrm{D}$-form peptide. The PNAs are written from their $\mathrm{N}$ to $\mathrm{C}$ termini, and the $\mathrm{N}$ terminus corresponds to the $5^{\prime}$ end of a conventional oligonucleotide. K: lysine. F: phenylalanine. eg1: 8-amino-3,6-dioxaoctanoyl.

\begin{tabular}{|c|c|c|c|c|c|c|c|c|}
\hline \multirow{2}{*}{ PNA No. } & \multirow{2}{*}{ Sequence $\mathbf{N} \rightarrow \mathbf{C}$} & \multirow{2}{*}{$\begin{array}{l}\text { Target } \\
\text { Position }\end{array}$} & \multirow{2}{*}{ Peptide } & \multicolumn{5}{|c|}{$\operatorname{MIC}(\mu \mathrm{M})$} \\
\hline & & & & $\begin{array}{c}\text { ATCC } \\
19606\end{array}$ & AC44 & AC46 & SSI 1104 & AC2 \\
\hline $5652(\mathrm{~m}) *$ & ATATCGCTCAC & +40 to $+50^{b}$ & $\mathrm{H}-(\mathrm{KFF})_{3} \mathrm{~K}-\mathrm{eg} 1$ & 4 & 4 & 4 & 4 & 4 \\
\hline $5653(\mathrm{~mm}) *$ & ATACCCGCTTAC & & $\mathrm{H}-(\mathrm{KFF})_{3} \mathrm{~K}-\mathrm{eg} 1$ & 4 & 4 & 4 & 4 & 4 \\
\hline $5639(\mathrm{~m})$ * & TGATTTGCC̄AC & +1 to $+11^{\mathrm{a}}$ & $\mathrm{H}-(\mathrm{KFF})_{3} \mathrm{~K}-\mathrm{eg} 1$ & 2 & 1 & 1 & 2 & $1-2$ \\
\hline $5640(\mathrm{~mm}) *$ & TGAㅡTTGTCAC & & $\mathrm{H}-(\mathrm{KFF})_{3} \mathrm{~K}-\mathrm{eg} 1$ & 4 & 4 & 4 & 4 & 4 \\
\hline $5639(\mathrm{~m})^{* *}$ & TGATTTGC'CAC & +1 to $+11^{\mathrm{a}}$ & $\mathrm{H}-(\mathrm{KFF})_{3} \mathrm{~K}-\mathrm{eg} 1$ & 4 & 4 & 4 & 4 & 4 \\
\hline $5640(\mathrm{~mm}) * *$ & TGACTTGTCAC & & $\mathrm{H}-(\mathrm{KFF})_{3} \mathrm{~K}-\mathrm{eg} 1$ & 4 & 4 & 4 & 4 & 4 \\
\hline $5823(\mathrm{~m}) *$ & TGATTTGCCAC & +1 to $+11^{\mathrm{a}}$ & $\mathrm{H}-(\mathrm{kff})_{3} \mathrm{k}-\mathrm{eg} 1^{\mathrm{c}}$ & 4 & 4 & 4 & 4 & 4 \\
\hline $5824(\mathrm{~mm}) *$ & TGACTTGTCAC & & $\mathrm{H}-(\mathrm{kff})_{3} \mathrm{k}-\mathrm{eg} 1^{\mathrm{c}}$ & 8 & 4 & 4 & 8 & 8 \\
\hline
\end{tabular}

\subsubsection{FtsZ}

The $f t s Z$ gene has frequently been used as an antibacterial antisense target $[17,21,22]$ and it is well conserved across A. baumannii species. BLAST results confirmed that the $5^{\prime}$ terminal region of the $f t s Z$ gene including the ribosomal binding site and the start ATG codon is conserved among A. baumannii species (Figure S1-A). A. baumannii strains and target genes that were examined for designing antisense in this study are shown in Table S2.

\subsubsection{RNase E}

RNase $\mathrm{E}$ is an essential bacterial endoribonuclease involved in the turnover of messenger RNA and the maturation of structured RNA precursors (rRNA and tRNA processing) in E. coli $[23,24]$. The major initiator of bacterial mRNA decay is considered to be a multiprotein complex termed the RNA degradosome. This complex is best characterized in the Gram-negative model organism, Escherichia coli, and consists of at least four subunits: RNA helicase B (RhlB), enolase, polynucleotide phosphorylase (PNPase), and RNase E. RNase $\mathrm{E}$ is the central component of the E. coli degradosome, establishing a scaffold for the assembly of other degradosome subunits and performing the initial endoribonucleolytic event during substrate mRNA decay. Thus, RNase E may represent a promising novel multi-function antimicrobial target. However, this enzyme has so far not been exploited for antisense antibiotic discovery.

In the genome of A. baumannii AYE strain, the rne gene encodes the 1110-amino acid protein (ABAYE3375). The BlastP analysis revealed an amino acid sequence identity of $60.5 \%$ with the E. coli RNase E. Thus, there is significant homology between RNase E in E. coli and RNase $\mathrm{E}$ in A. baumannii, and in addition the rne gene is well conserved across A. baumannii species. The BLAST results confirmed that the $5^{\prime}$ terminal region of the rne gene including the ribosomal binding site and the ATG start codon is conserved among A. baumannii species (Figure S1-B). In this study, four 11-mer targets overlapping the translation start were chosen. 


\subsection{MIC and Time Kill Kinetics}

We evaluated the antibacterial activity of the compounds by determining the minimum inhibitory concentration (MIC) against several A. baumannii strains. The target positions, PNA sequences, CPP, and MIC values are presented below. In case of acpP, according to the variation in gene size (vide supra), we designed the antisense oligomers to cover both possible start codon regions (Table 1). The MIC value for PNA 5652 targeting the "downstream" GTG was $4 \mu \mathrm{M}$ in all tested strains, but importantly, when an analogous mismatch PNA control (5653) was tested, no difference in activity was found when compared with the match PNA (5652) (Table 1). Thus, the antibacterial activity could not be assigned to an antisense mechanism of action. However, significant difference between the MIC values of PNA 5639 (targeting the upstream GTG start codon) was found compared with the analogous mismatch control PNA (5640) (Table 1, Figure 1, Figure S5-A). In addition, bactericidal activity of PNA 5639 was characterized against A. baumannii ATCC 19606 strain. The ATCC 19606 strain was exposed to 4 or $8 \mu \mathrm{M}$ of PNA 5639 (and control) for $6 \mathrm{~h}$. As shown in Figure 2, this compound showed fast bactericidal activity resulting in a 4 log reduction after $3 \mathrm{~h}$ treatment. The potency of this compound was 1-4-fold decreased when tested in cation adjusted MHB (because divalent cations can stabilize bacterial membranes). Finally, changing the BPP form the natural L-form to the D-form (PNAs 5823 and 5824) reduced both activity and antisense (match/mismatch) specificity.
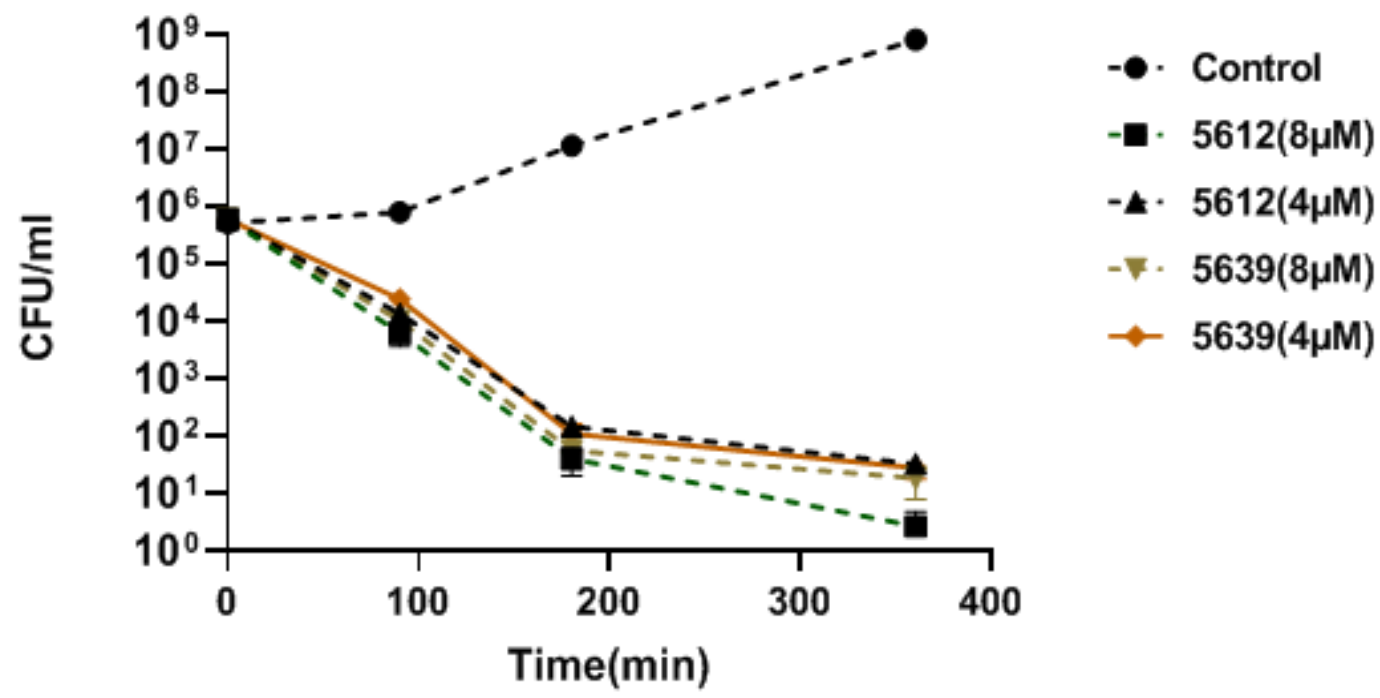

Figure 2. Killing kinetics of anti-acpP peptide-PNA (5639) and anti-ftsZ peptide-PNA (5612) conjugates against A. baumannii ATCC 19606. Strain was grown in the absence of peptide-PNA conjugate (control) or in the presence of MIC and $2 \times$ MIC of anti-acpP peptide-PNA (5639) and anti-ftsZ peptide-PNA (5612). Each point value represents the mean of two independent experiments with at least two technical replicates for each experiment. MHB without cation (Sigma) was used.

PNA 5612 (Figure 3) was the most active of the anti ftsZ PNAs. The MIC values for this compound ranged from 4 to $8 \mu \mathrm{M}$ and was 2-4-fold lower than for the corresponding mismatch control PNA (5615) (Table 2), corroborating an antisense mechanism of action. The bactericidal activity of PNA 5612 was characterized against the A. baumannii ATCC 19606, and as shown in Figure 2, the compound exhibited fast bactericidal activity yielding more than three order of magnitude CFU reduction after $3 \mathrm{~h}$ at $4 \mu \mathrm{M}$. Furthermore, PNA5612 showed good activity against 12 multidrug resistant clinical isolates with MIC values ranging from 2-8 $\mu \mathrm{M}$ and exhibiting a 2-8-fold match/mismatch ratio (Table 3, Figure S5-B). Finally, exchanging the (KFF) ${ }_{3} \mathrm{~K}$ BPP for the (R-Ahx-R $)_{4}$ BPP, which has been used successfully e.g., in E. coli and Pseudomonas aeruginosa [17] yielded a significantly less potent compound (PNA5613, MIC > 16M) (Table 2). 


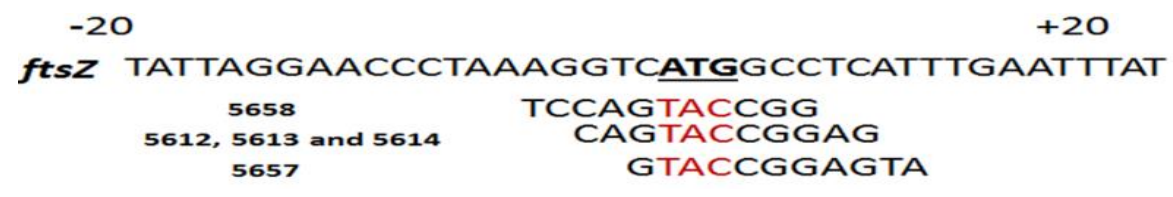

Figure 3. Sequence from the ftsZ mRNA and positions of the PNA targets.

Table 2. PNAs targeted to the ftsZ gene of A. baumannii AYE are displayed with their designation numbers. Minimum inhibitory concentrations $(\mu \mathrm{M})$ of anti-ftsZ CPP-PNAs and mismatch control against CRAB strains. MHB without cation (Oxoid) was used. m: Match, mm: Mismatch. The PNAs are written from their $\mathrm{N}$ to $\mathrm{C}$ termini, and the $\mathrm{N}$ terminus corresponds to the $5^{\prime}$ end of a conventional oligonucleotide. K: lysine, F: phenylalanine. R: arginine. Ahx: 6-aminohexanoyl. eg1: 8-amino-3,6-dioxaoctanoyl. nd: not determined.

\begin{tabular}{|c|c|c|c|c|c|c|}
\hline \multirow[b]{2}{*}{ PNA No } & \multirow[b]{2}{*}{ Sequence $\mathbf{N} \rightarrow \mathbf{C}$} & \multirow[b]{2}{*}{ Target Position } & \multirow[b]{2}{*}{ Peptide } & \multicolumn{3}{|c|}{$\operatorname{MIC}(\mu \mathrm{M})$} \\
\hline & & & & $\begin{array}{l}\text { ATCC } \\
19606\end{array}$ & AC44 & SSI1104 \\
\hline $5612(\mathrm{~m})$ & GAGGCCATGAC & -3 to +8 & $\mathrm{H}-(\mathrm{KFF})_{3} \mathrm{~K}-\mathrm{eg} 1$ & 4 & 8 & 4 \\
\hline $5615(\mathrm{~mm})$ & GAGTCCAGGAC & & $\mathrm{H}-(\mathrm{KFF})_{3} \mathrm{~K}-\mathrm{eg} 1$ & 8 & 16 & 16 \\
\hline $5613(\mathrm{~m})$ & GAGGCCATGAC & -3 to +8 & $\mathrm{H}-(\mathrm{R}-\mathrm{Ahx}-\mathrm{R})_{4}-\mathrm{Ahx}$ & $>16$ & $>16$ & nd \\
\hline $5616(\mathrm{~mm})$ & GAGTCCAGGAC & & $\mathrm{H}-(\mathrm{R}-\mathrm{Ahx}-\mathrm{R})_{4}-\mathrm{Ahx}$ & $>16$ & $>16$ & nd \\
\hline $5657(\mathrm{~m})$ & ATGAGGCCATG & -1 to +10 & $\mathrm{H}-(\mathrm{KFF})_{3} \mathrm{~K}-\mathrm{eg} 1$ & $>16$ & 16 & nd \\
\hline $5658(\mathrm{~m})$ & GGCCATGACCT & -5 to +6 & $\mathrm{H}-(\mathrm{KFF})_{3} \mathrm{~K}-\mathrm{eg} 1$ & 4 & 8 & 8 \\
\hline
\end{tabular}

Table 3. Minimum inhibitory concentrations of the most potent Anti-ftsZ CPP-PNA (5612) and mismatch control (5615) against the CRAB and ATCC 19606 strains. MHB without cation (Oxoid) was used.

\begin{tabular}{ccc}
\hline Strains & H-(KFF) ${ }_{3}$ K-eg1-ftsZ PNA(5612) & H-(KFF) ${ }_{3}$ K-eg1-ftsZ PNA(5615) $^{\text {Pre }}$ \\
\hline ATCC19606 & $4 \mu \mathrm{M}$ & $8 \mu \mathrm{M}$ \\
AC1 & $4 \mu \mathrm{M}$ & $16 \mu \mathrm{M}$ \\
AC2 & $2 \mu \mathrm{M}$ & $16 \mu \mathrm{M}$ \\
AC3 & $4 \mu \mathrm{M}$ & $8 \mu \mathrm{M}$ \\
AC4 & $8 \mu \mathrm{M}$ & $16 \mu \mathrm{M}$ \\
AC5 & $4 \mu \mathrm{M}$ & $16 \mu \mathrm{M}$ \\
AC6 & $4 \mu \mathrm{M}$ & $8 \mu \mathrm{M}$ \\
AC7 & $4 \mu \mathrm{M}$ & $16 \mu \mathrm{M}$ \\
AC8 & $8 \mu \mathrm{M}$ & $16 \mu \mathrm{M}$ \\
AC9 & $2 \mu \mathrm{M}$ & $16 \mu \mathrm{M}$ \\
AC44 & $8 \mu \mathrm{M}$ & $16 \mu \mathrm{M}$ \\
AC46 & $8 \mu \mathrm{M}$ & $16 \mu \mathrm{M}$ \\
SSI104 & $4 \mu \mathrm{M}$ & $16 \mu \mathrm{M}$ \\
MIC50 & $4 \mu \mathrm{M}$ & $16 \mu \mathrm{M}$ \\
\hline
\end{tabular}

Finally, for the rne gene, four different $(\mathrm{KFF})_{3} \mathrm{~K}$-PNAs were design targeting the start codon in different registers (Figure 4, Table 4). MIC determination showed that PNA5656 ( -5 to +6 register) was the most active, yielding a MIC of $2 \mu \mathrm{M}$ and a four-fold mismatch discrimination. Concentration dependent bactericidal activity was determined on the highly antibiotic resistant clinical isolate AC46 in a concentration range from 1-8 $\mu \mathrm{M}$ (Figure 5) and showed very significant CFU reduction by the match PNA compared to the corresponding mismatch control PNA (5822), thus supporting that rne gene expression is essential for A. baumannii survival. 


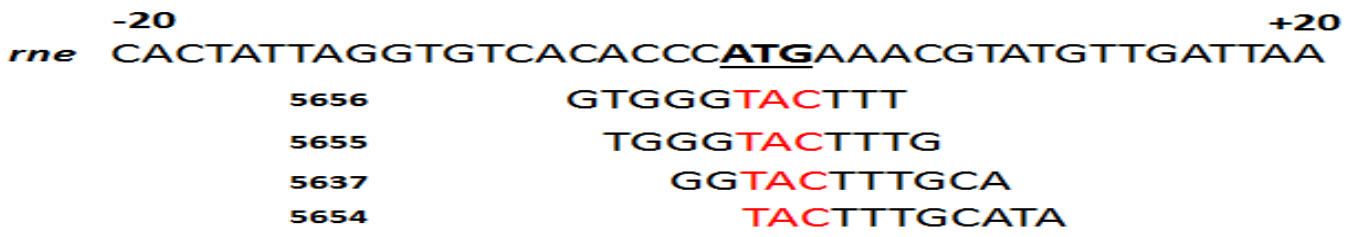

Figure 4. Sequence from the rne mRNA and positions of the PNA targets.

Table 4. PNAs targeted to the start-codon region of the rne gene of A. baumannii AYE are displayed with their designation numbers. The MIC values $(\mu \mathrm{M})$ for the four CRAB strains are presented compared to that for the standard ATCC19606 strain. m: Match, mm: Mismatch. The PNAs are written from the $\mathrm{N}$ to $\mathrm{C}$ termini, and the $\mathrm{N}$ terminus corresponds to the $5^{\prime}$ end of a conventional oligonucleotide. K: lysine. F: phenylalanine. eg1: 8-amino-3, 6-dioxaoctanoyl. nd: not determined.

\begin{tabular}{|c|c|c|c|c|c|c|c|c|}
\hline \multirow[b]{2}{*}{ PNA No } & \multirow[b]{2}{*}{ Sequence $\mathbf{N} \rightarrow \mathbf{C}$} & \multirow[b]{2}{*}{$\begin{array}{c}\text { Target } \\
\text { Position }\end{array}$} & \multirow[b]{2}{*}{ Peptide } & \multicolumn{5}{|c|}{$\operatorname{MIC}(\mu \mathrm{M})$} \\
\hline & & & & $\begin{array}{l}\text { ATCC } \\
19606\end{array}$ & AC44 & AC46 & SSI 1104 & $\mathrm{AC} 2$ \\
\hline $5637(\mathrm{~m})$ & ACGTTTCATGG & -2 to +9 & $\mathrm{H}-(\mathrm{KFF})_{3} \mathrm{~K}-\mathrm{eg} 1$ & 1 & 1 & 1 & nd & nd \\
\hline $5638(\mathrm{~mm})$ & ACGATTCTTGG & & $\mathrm{H}-(\mathrm{KFF})_{3} \mathrm{~K}-\mathrm{eg} 1$ & 2 & 2 & 1 & nd & nd \\
\hline $5654(\mathrm{~m})$ & ATACGTTTCAT & +1 to +11 & $\mathrm{H}-(\mathrm{KFF})_{3} \mathrm{~K}-\mathrm{eg} 1$ & 2 & 1 & 2 & 2 & 2 \\
\hline $5821(\mathrm{~mm})$ & ATCCGTTTA AAT & & $\mathrm{H}-(\mathrm{KFF})_{3} \mathrm{~K}-\mathrm{eg} 1$ & $\overline{4}$ & 1 & 2 & 2 & 2 \\
\hline $5656(\mathrm{~m})$ & TTTCATGGĞTG & -5 to +6 & $\mathrm{H}-(\mathrm{KFF})_{3} \mathrm{~K}-\mathrm{eg} 1$ & 2 & 2 & 2 & 2 & 2 \\
\hline $5822(\mathrm{~mm})$ & TTTGATGTGTG & & $\mathrm{H}-(\mathrm{KFF})_{3} \mathrm{~K}-\mathrm{eg} 1$ & 8 & 8 & 8 & 8 & 8 \\
\hline $5655(\mathrm{~m})$ & GTTTCATGGGT & -4 to +7 & $\mathrm{H}-(\mathrm{KFF})_{3} \mathrm{~K}-\mathrm{eg} 1$ & 4 & 8 & nd & nd & 8 \\
\hline
\end{tabular}

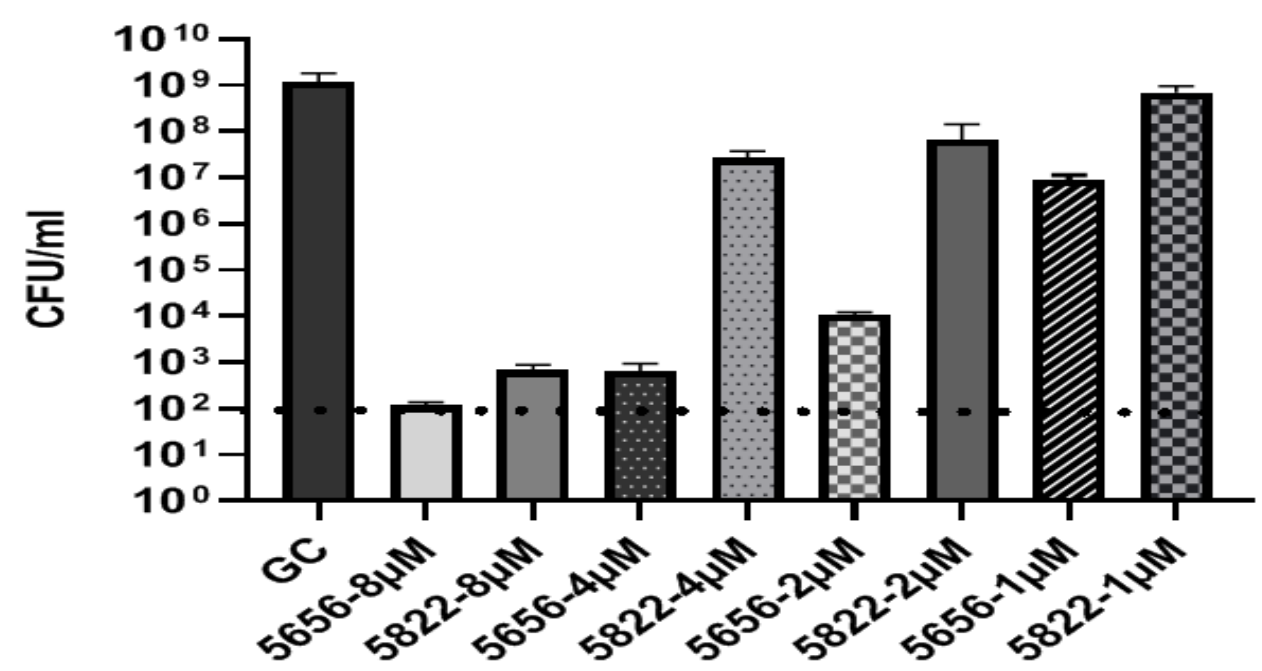

Figure 5. Minimum bactericidal concentration (MBC) assays for the BPP-anti-rne PNA (5656) and mismatch control (5822) in antibiotic resistant clinical isolate AC46 after $24 \mathrm{~h}$ incubation and concentration range from 1-8 $\mu \mathrm{M}$. Dashed line represents the limit of detection.

\subsection{Species-Selective Activity of BPP-PNAs}

In principle, a specific antisense PNA-peptide conjugate should only show activity against species that harbor the sequence target for the PNA in a sensitive essential gene position (e.g., overlapping the ribosome binding site and/or the translation initiation codon), and in which the conjugate is taken up. Thus, the A. baumannii active PNAs 5612, 5639 , and 5652 were also tested for activity against E. coli and P. aeruginosa as a non-target species where no obvious gene target match for the PNAs exists. The results (Table 5) also clearly show that neither of these PNAs are active against E. coli and P. aeruginosa, thereby illustrating species specific/selective activity of these precision antisense antibiotics. In addition, a fourth analogous PNA (3965) without obvious target in any of the three species likewise did not show activity against these either. 
Table 5. Antibacterial activity of the most active compounds, anti-ftsZ (KFF) ${ }_{3} \mathrm{~K}-\mathrm{PNA}$ and anti-acpP (KFF) ${ }_{3} \mathrm{~K}-\mathrm{PNA}$, against both target and non-target species. " In addition, the antibacterial activity of compound 3965 (designed against the ftsZ gene in E. coli with two base mismatches) against ATCC and CRAB strains is shown here. MHB without cation (Oxoid) was used. * Conjugated to $\mathrm{H}-(\mathrm{KFF})_{3} \mathrm{~K}-\mathrm{eg} 1-$ at the N-terminal. m: Match. mm: Mismatch. nd: not determined.

\begin{tabular}{|c|c|c|c|c|c|c|}
\hline & & & $\operatorname{MIC}(\mu \mathrm{M})$ & $\operatorname{MIC}(\mu \mathrm{M})$ & $\operatorname{MIC}(\mu \mathrm{M})$ & $\mathrm{MIC}(\mu \mathrm{M})$ \\
\hline Target & PNA & Sequence * & $\begin{array}{l}\text { P. aeruginosa } \\
\text { (PAO1) }\end{array}$ & $\begin{array}{c}\text { E. coli K-12 } \\
\text { MG1655 }\end{array}$ & $\begin{array}{c}\text { A. baumannii } \\
\text { ATCC } 19606\end{array}$ & $\begin{array}{l}\text { A. baumannii } \\
\text { SSI1104 }\end{array}$ \\
\hline ftsZ (m) & 5612 & GAGGCCATGAC & $>16 \mu \mathrm{M}$ & $>16 \mu \mathrm{M}$ & $4 \mu \mathrm{M}$ & $4 \mu \mathrm{M}$ \\
\hline $\operatorname{acp} P(\mathrm{~m})$ & 5639 & TGATTTGCCAC & $>16 \mu \mathrm{M}$ & $>16 \mu \mathrm{M}$ & $2 \mu \mathrm{M}$ & $2 \mu \mathrm{M}$ \\
\hline $\operatorname{acp} P(\mathrm{~m})$ & 5652 & ATATCGCTCAC & $16 \mu \mathrm{M}$ & $16 \mu \mathrm{M}$ & $4 \mu \mathrm{M}$ & $4 \mu \mathrm{M}$ \\
\hline $\mathrm{ftsZ}(\mathrm{mm}){ }^{\#}$ & 3965 & TTCTAACAㅁAAGT & nd & $16 \mu \mathrm{M}$ & $16 \mu \mathrm{M}$ & $\geq 16 \mu \mathrm{M}$ \\
\hline
\end{tabular}

\subsection{Cytotoxicity}

It is well established that cationic peptides in general can exhibit mammalian cellular toxicity. Thus, a toxicity characterization was performed in a standard in vitro HepG2 cell culture assay based on mitochondrial activity. These results showed significant difference in eukaryotic cell toxicity between PNA 5612 and 5639 compared to PNA 5613 (Figure 6). After $24 \mathrm{~h}$ of exposure to $20 \mu \mathrm{M}$ of BPP-PNAs, the highest concentrations of BPP-PNAs tested resulted in 8-20\% reduction in cell viability for BPP-PNAs 5639 and 5612, while exposure to the MIC50 concentration $(2-4 \mu \mathrm{M})$ resulted in no reduction in viability for both PNAs 5639 and 5612. Notably, the H-(R-Ahx-R)4-Ahx-PNA 5613 showed very significant toxicity at $10 \mu \mathrm{M}(\mathrm{EC} 50$ was between 5 and $10 \mu \mathrm{M})$.

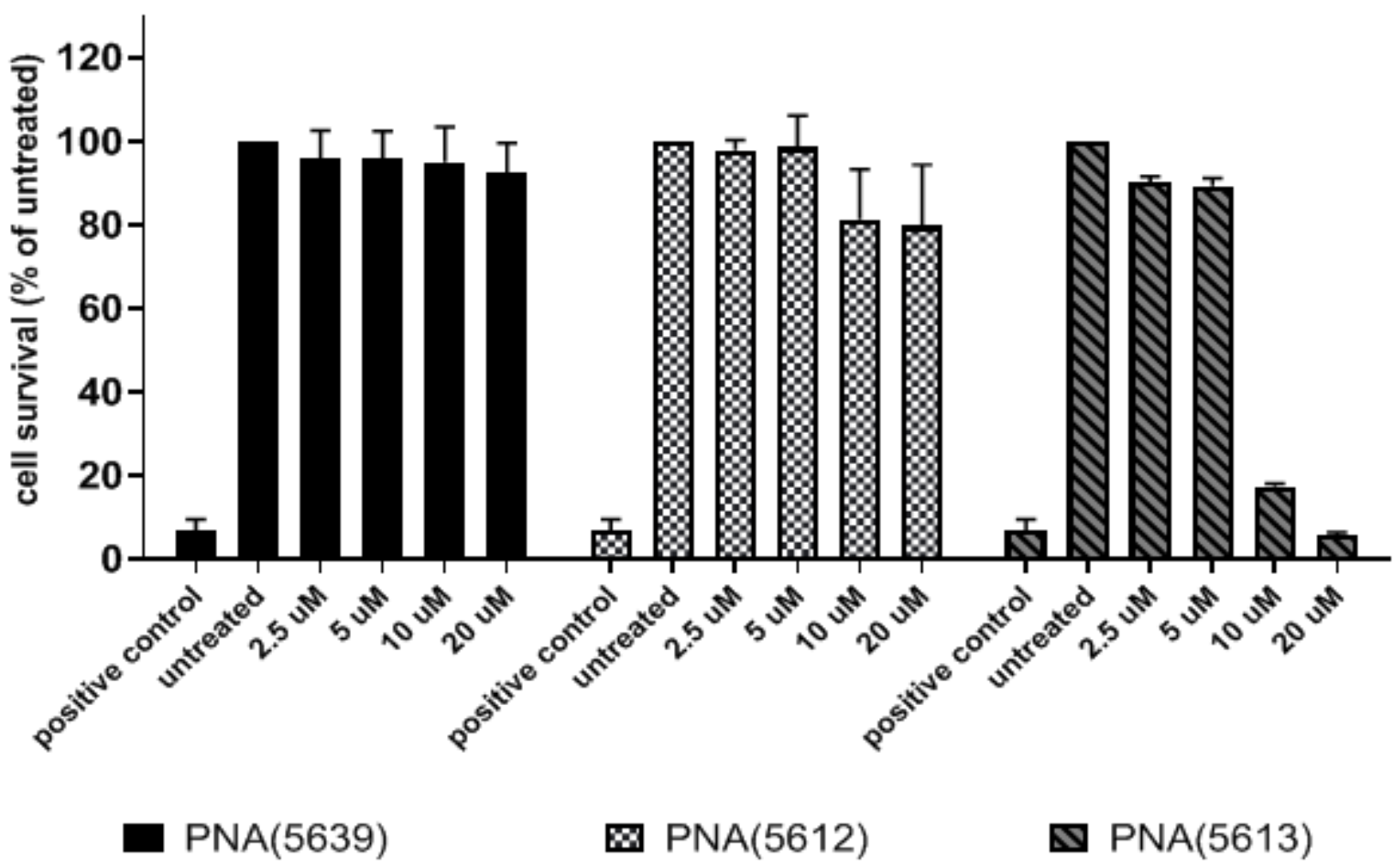

Figure 6. Cell viability assay of anti-acpP $(\mathrm{KFF})_{3} \mathrm{~K}-\mathrm{PNA} 5639$, anti-ftsZ (KFF) ${ }_{3} \mathrm{~K}-\mathrm{PNA} 5612$, and anti-ftsZ(R-Ahx-R $)_{4}$-AhxPNA 5613 in HepG2 cell culture. Cell viability was quantified by ATP level. The data are presented as the mean of normalized percentage of two individual experiments (each comprising six replicates for each concentration) relative to untreated cells (error bars represent SEM). Potassium dichromate $(100 \mu \mathrm{M})$ was used as a positive control. 


\subsection{Envelope Disruption}

Structurally BPPs are related to antimicrobial peptides containing both cationic and hydrophobic amino acids (exemplified by lysine and arginine, and phenylalanine and amino hexanoic acid in the peptides used here) and some antimicrobial peptides may even be employed as BPPs [20,25]. Therefore, non-antisense-related activity as seen for some of the BPP-PNAs in this study could be due to membrane/envelope disruption. This may be tested using the DNA binding fluorescent dye Sytox, which is not taken up by live, intact bacteria. However, cell envelope disruption leads to cellular uptake of the Sytox, resulting in an enhanced fluorescence due to DNA binding of the dye which can be observed in both a concentration- and time-dependent manner. Colistin, a known membrane-disrupting agent, was used as a positive control. However, the Sytox uptake assay gave no indication of membrane disruption activity of the anti-acpP $(\mathrm{KFF})_{3}$-K-PNA 5639 and anti-ftsZ $(\mathrm{KFF})_{3}$ K-PNA 5612 even at $2 \times$ MIC concentration $(4 \mu \mathrm{M})$, and only a minimal effect at $8 \mu \mathrm{M}$, in sharp contrast to the effect of colistin (Figure 7).
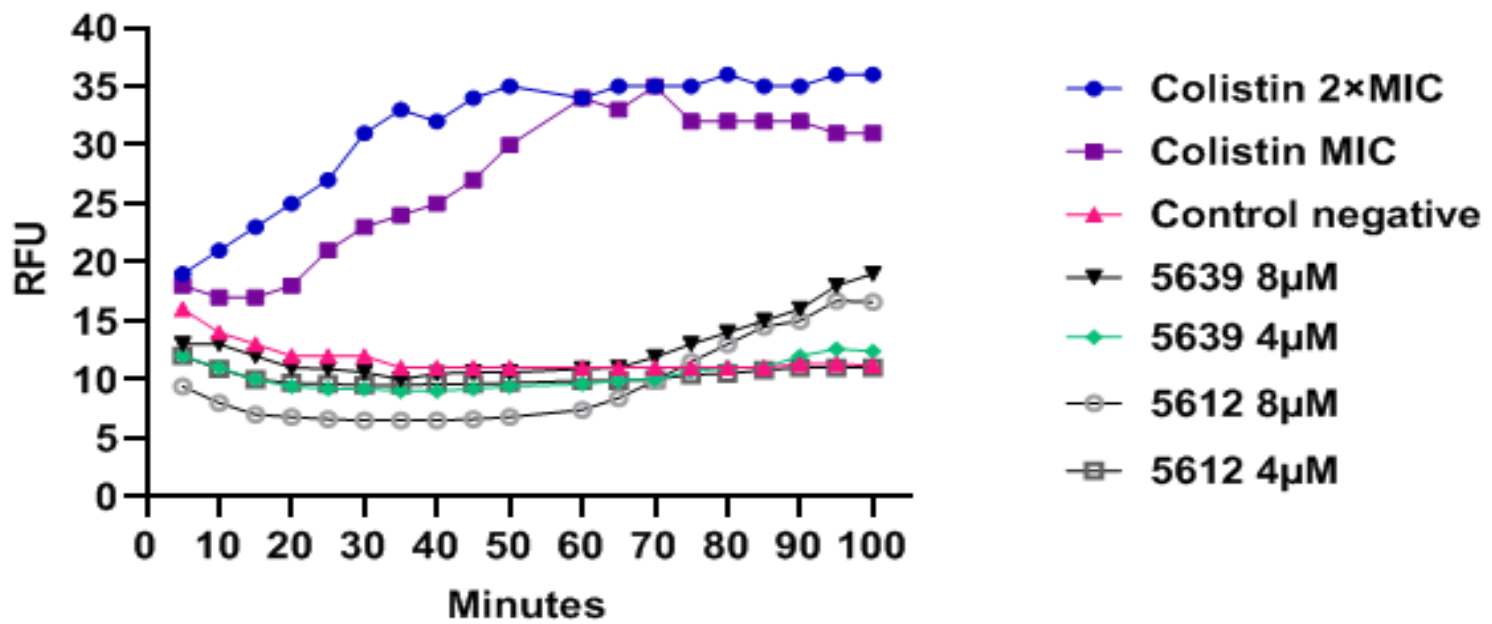

Figure 7. Membrane disruption Sytox assay in A. baumannii ATCC 19606. Membrane disruption activity of anti-acpP $(\mathrm{KFF})_{3} \mathrm{~K}-\mathrm{PNA} 5639$ and anti-ftsZ (KFF) ${ }_{3}$ K-PNA 5612 was measured by fluorescence intensity of internalized Sytox. Colistin was used as positive control.

\subsection{Effect on Target $m R N A$}

The molecular antisense mechanism of PNA oligomers in bacteria is believed to rely on translation inhibition via steric blockage of ribosome assembly on the mRNA. In other words, antisense PNA silencing in bacteria leads to translation repression and presumably unmasking of the mRNA. The mRNA unmasking may in turn lead to (nonsense mediated) decay [24]. In order to address whether such a mechanism is involved in the activities observed with the present BPP-PNAs, mRNA levels for the target genes were determined by RT-real time PCR. Specifically, the impact of different concentrations of anti-acpP $(\mathrm{KFF})_{3}$ K-PNA 5639 and the corresponding mismatch control 5640 on the expression level of the acpP mRNA was analyzed (Figure 8). A significant reduction in the level of the acpP mRNA was observed upon treatment with BPP-PNA 5639 (>34-fold reduction) (Figure S6-A), while only a minor reduction was observed with the corresponding mismatch control BPP-PNA 5640 (4-fold reduction) (Figure S6-B). The differences in the relative expression of the acpP gene upon treatment with BPP-PNA 5640 was not statistically significant $(p$-value $=0.059$, two-tailed Student's $t$-test). We also find a reduction (up to $60 \%)$ in $f t s Z$ mRNA $1 \mathrm{~h}$ after treatment with anti-ftsZ (KFF) ${ }_{3} \mathrm{~K}-\mathrm{PNA} 5612$ (match) in the AC44 strain, while only a minor reduction was observed with the corresponding mismatch control PNA (up to $28 \%$, Figure 8 ). 

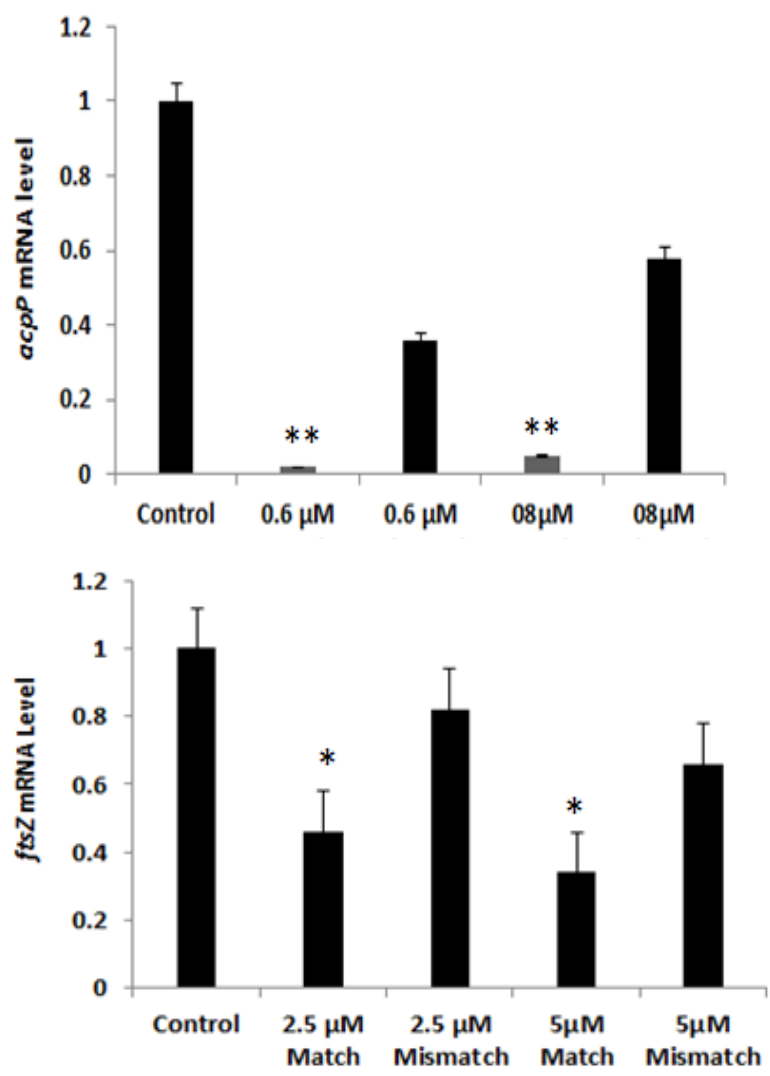

Figure 8. The acpP mRNA level in the CRAB AC44 strain after one hour treatment with antiacpP (KFF) ${ }_{3}$ K-PNA 5639 (match) or anti-acpP (KFF) ${ }_{3}$ K-PNA 5640 (mismatch) compared with the untreated control. Gene expression levels were normalized to $16 \mathrm{~S}$ rRNA through $-\Delta \mathrm{Ct}$ analysis and are presented as fold change versus control (untreated sample) calculated by the- $\Delta \Delta \mathrm{Ct}$ method. The ftsZ mRNA level in the CRAB AC44 strain after one hour treatment with anti-ftsZ (KFF) ${ }_{3} \mathrm{~K}$ PNA 5612 (match) or anti-ftsZ (KFF) ${ }_{3}$ K-PNA 5615 (mismatch) compared with the untreated control. Error bars depict standard error of the mean. The presented data represents averages of triplicate determinations, performed at least two times. Comparison of each treatment with a control was done via two-tailed Student's $t$-test ${ }^{*}=p \leq 0.05,{ }^{* *}=p \leq 0.01$ ). As well, a comparison between BPP-PNA match and BPP-PNA mismatch with an untreated sample was performed via a one way ANOVA.

\section{Discussion}

The present study has identified three antisense $(\mathrm{KFF})_{3}-\mathrm{K}-\mathrm{PNA}$ conjugates targeting the translation initiation site of the mRNA of the acpP (PNA5639), ftsZ (PNA5612), and rne (PNA5656) genes, respectively, which exhibit bactericidal activity against carbapenemresistant $A$. baumannii at $4 \mu \mathrm{M}$, while showing no significant cytotoxicity in HepG2 cells at $20 \mu \mathrm{M}$. An antisense mechanism of action was corroborated by the significantly lower activity of double mismatch controls, reduction of target mRNA levels upon PNA treatment, as well lack of membrane disruption activity. In addition, analogous BPP-PNAs based on the D-form (KFF) ${ }_{3}-\mathrm{K}$ peptide or the frequently used arginine rich (R-Ahx-R $)_{4}$ showed inferior antibacterial activity. Finally, the anti-ftsZ PNA5612 was active against 12 CRAB clinical isolates.

Previously, several essential as well as non-essential genes have been targeted by BPP-PNA oligomers in A. baumannii [21,26-28]. Rose et al. [28] tested a (RXR) ${ }_{4}$ XB-carA PNA oligomer (targeting car $A$ as an essential gene) against four clinical strains of MDR- $A$. baumannii in minimal medium (M9). The MIC results demonstrated that all four strains were inhibited at a concentration of $1.25 \mu \mathrm{M}$ (the low MIC most probably is related to the use of M9 minimal medium, as discussed below). In addition, in vivo testing of the BPP-PNA oligomer was done using a Galleria mellonella model of sepsis caused by one 
of the clinical strains. Unfortunately, this study suffers from the absence of an antisense mismatch control, and it is therefore not possible to ascribe the effects to an antisense mechanism of action. Guitian et al. [26] in another study found that the $l p x B$ gene is a possible target for $A$. baumannii. They showed that a $(\mathrm{KFF})_{3} \mathrm{~K}-l p x B$ PNA inhibiting $l p x B$ expression is bactericidal and found that this PNA showed higher antimicrobial activity in M9 compared to LB medium and ascribed the enhanced activity in M9 to the lower bacterial growth rate due to nutrient limitations in the M9 medium. We observed that using the M9 medium (with added glucose), overnight cultures only reached $\mathrm{OD}_{595}$ between 0.1 to 0.2 , and therefore considered this unsuitable for MIC analyses.

Geller et al. [21] examined the effects of BPP-PMO oligomers targeting several essential genes (acpP, ftsZ, and rpsJ) against two ATCC strains (ATCC17978 and ATCC19606) and three clinical strains (AYE, M9, and AB0057) of A. baumannii. The most active anti acpP PMO was an R-Ahx conjugate (R-Ahx-R) 4 -Ahx-acpP; 08-0163 in the study) which exhibited MIC values of $8 \mu \mathrm{M}$ (for ATCC strains) and 2 to $4 \mu \mathrm{M}$ for clinical strains of $A$. baumannii. It is noteworthy that this PMO was designed to target the ATG codon at position +25 in the present database annotation (see Figure 1) [21], and therefore probably is not optimal for translation inhibition. Additionally, the mammalian cellular toxicity (in vitro) of the (R-Ahx-R $)_{4}$-Ahx-acpP-PMO was not addressed, and a general, random sequence control instead of a specific mismatch control was used to demonstrate target specificity. In vivo experiments in a pulmonary infection model using intranasal administration showed efficacy of the compound, but significant effect was also observed for the random sequence control [21].

In our study, we selected new regions of $a c p P$ mRNA in accordance with the newly annotated translation initiation site(s) in the A. baumannii acp $P$ gene and find that a KFFbased anti acpP-PNA which has not been studied before in A. baumannii shows higher antibacterial activity than the (R-Ahx-R $)_{4}$-Ahx-acpP-PMO reported by Geller study [21]. For instance, the MIC of most active anti acpP compound in Geller study against ATCC19606 was $8 \mu \mathrm{M}$, while in our study, the MIC of the (KFF) $)_{3}-\mathrm{K}$-eg1-acpP PNA (5639) against ATCC19606 was $2 \mu \mathrm{M}$.

In the case of the ftsZ gene, Geller et al. [21] studied only one region of the ftsZ mRNA ( +4 to +14 (see Figure 3$)$ ) using an $(\mathrm{RFF})_{3} \mathrm{R}-\mathrm{PMO}$. The MIC values of this PMO compound ranged from 16 to $64 \mu \mathrm{M}$ against different strains of $A$. baumannii (because of the high MIC value, they did not report further studies on the compound). In the present study, antimicrobial activity optimization of several BPP-PNA oligomers targeting different regions of the $f t s Z$ gene (near the start codon and RBS) resulted in an anti ftsZ PNA with MIC values ranging from 2 to $8 \mu \mathrm{M}$ against a broad panel of clinical CRAB isolates. Surprisingly, the analogous (R-Ahx-R) ${ }_{4}$-Ahx PNA (5613) did not show significant antibacterial activity.

RNase E, coded for by the rne gene, is a central enzyme in RNA processing and metabolism [23,29], and therefore constitute a possible and interesting, but unexplored target for future precision antisense antibiotics. The present results demonstrate that antimicrobial anti-rne BPP-PNAs with MIC values of $2 \mu \mathrm{M}$ against CRA can be found and may indeed be worth pursuing further.

Unfortunately, no systematic studies are yet available comparing directly the efficacy of fully analogous PNA and PMO antibacterial agents. Similarly, systematic comparison of the individual BPP carrier efficiency in different bacterial species is not available either. However, several studies have clearly shown that different bacterial species do respond differently to BPPs. For instance, the $(\mathrm{KFF})_{3} \mathrm{~K}$ peptide which is effective in e.g., E. coli as well as A. baumannii (as shown here) is not efficient in P. aeruginosa [17], whereas the (R-ahx-R $)_{4}$ peptide is a potent BPP in both E. coli and P. aeruginosa. Likewise, analogous $\mathrm{BPP} /$ bacteria activity differences have been reported for Burkholderia versus Pseudomonas and Acinetobacter [30-32]. Furthermore, some peptides seem to work better in Grampositive than in Gram-negative species [32], as can be expected from the significantly different envelope structures, Finally, although the PNA has extremely high biostability, the 
peptides are much less stable as exemplified by the $(\mathrm{KFF})_{3} \mathrm{~K}$ peptide, which has a half-life of less than $5 \mathrm{~min}$ in exponential bacterial culture [33]. This undoubtedly will vary with bacterial strain, medium, and bacterial density, and should also be taken into consideration when comparing and evaluating BPPs.

\section{Conclusions}

In conclusion, a series of new antisense PNA-peptide conjugates targeting translation of essential genes ( $a c p P, f t s Z$, and $r n e$ ) have been identified and characterized in terms of low micromolar in vitro antibacterial activity against clinical isolates of carbapenem-resistant Acinetobacter baumannii. Therefore, these results provide new gene sequence targets and antisense BPP-PNA conjugate hit compounds for possible future development of precision antibiotics for treatment of infections by carbapenem-resistant Acinetobacter baumannii. The use of precision antibiotics will require genetically-based (PCR) diagnostics, and because predominantly the target pathogen is affected, any broad resistance development should be minimized. Further optimization of the compounds in the preclinical studies includes systematic gene walk around the identified target, also including target length variation [16] In addition, structure activity relation (SAR) studies in terms of the delivery peptide part are required in order to optimize both antibacterial potency, but especially pharmacokinetics and pharmacodynamics (including in vivo toxicity) in appropriate animal (mouse) infection models.

Supplementary Materials: The following are available online at https://www.mdpi.com/article/ 10.3390 /biomedicines 9040429 /s1, Multiple sequence alignment of $f t s Z$ and $r n e$ genes, Figure S2: A multiple sequence alignment of $a c p P$ gene, Figure S3: A multiple sequence alignment of AcpP proteins, Figure S4: The sequence of the acpP gene in $A$. baumannii and the other gram negative bacteria, Figure S5: Growth inhibition activity curve of the most active compounds against CRAB strains, Figure S6: Log2-fold change values determined by qPCR for acpP mRNA, Figure S7: Analytical HPLC and MALDI-TOF mass spectrometry results of the most active BPP-PNAs, Table S1: Clinical, phenotypic and genotypic characteristics of the CRAB in this study, Table S2: Acinetobacter baumannii strains that were examined for designing antisense in this study, Table S3: Anti-ftsZ BPP-PNA used in this study, Table S4: Anti-acpP BPP-PNA used in this study, Table S5: Anti-rne BPP-PNA used in this study, Table S6: Primers used in real time RT-PCR.

Author Contributions: A.J.N., N.S. and P.E.N. conceived and designed the experiments. A.J.N. performed the experiments. A.J.N. and P.E.N. analyzed the data. A.J.N. wrote the first draft of the manuscript. Writing, review and editing: A.J.N. and P.E.N.; Funding acquisition: P.E.N. All authors have read and agreed to the published version of the manuscript.

Funding: This work was financially supported by the NovoNordisk Foundation Challenge Program (NNF16OC0021700).

Institutional Review Board Statement: Not applicable.

Informed Consent Statement: Not applicable.

Data Availability Statement: Not applicable.

Acknowledgments: We are grateful to Jolanta Ludvigsen at Copenhagen University for technical assistance and also acknowledge the assistance of Tessa Munkeboe Hornsyld at Neuromuscular research unit of Copenhagen University with the real time PCR experiment. We thank Anette M. Hammerum (SSI, Copenhagen-Denmark) for kindly providing the SSI1104 strain.

Conflicts of Interest: The authors have no conflict of interest to declare.

\section{References}

1. Hsu, L.-Y.; Apisarnthanarak, A.; Khan, E.; Suwantarat, N.; Ghafur, A.; Tambyah, P.A. Carbapenem-Resistant Acinetobacter baumannii and Enterobacteriaceae in South and Southeast Asia. Clin. Microbiol. Rev. 2016, 30, 1-22. [CrossRef]

2. Wong, D.; Nielsen, T.B.; Bonomo, R.A.; Pantapalangkoor, P.; Luna, B.; Spellberg, B. Clinical and Pathophysiological Overview of Acinetobacter Infections: A Century of Challenges. Clin. Microbiol. Rev. 2016, 30, 409-447. [CrossRef] 
3. Isler, B.; Doi, Y.; Bonomo, R.A.; Paterson, D.L. New Treatment Options against Carbapenem-ResistantAcinetobacter baumanniiInfections. Antimicrob. Agents Chemother. 2018, 63. [CrossRef]

4. Esterly, J.S.; Griffith, M.; Qi, C.; Malczynski, M.; Postelnick, M.J.; Scheetz, M.H. Impact of Carbapenem Resistance and Receipt of Active Antimicrobial Therapy on Clinical Outcomes of Acinetobacter baumannii Bloodstream Infections. Antimicrob. Agents Chemother. 2011, 55, 4844-4849. [CrossRef] [PubMed]

5. Vogel, J. An RNA biology perspective on species-specific programmable RNA antibiotics. Mol. Microbiol. 2020, 113, 550-559. [CrossRef] [PubMed]

6. Wojciechowska, M.; Równicki, M.; Mieczkowski, A.; Miszkiewicz, J.; Trylska, J. Antibacterial Peptide Nucleic Acids—Facts and Perspectives. Molecules 2020, 25, 559. [CrossRef]

7. Good, L.; Awasthi, S.K.; Dryselius, R.; Larsson, O.; Nielsen, P.E. Bactericidal antisense effects of peptide-PNA conjugates. Nat. Biotechnol. 2001, 19, 360-364. [CrossRef] [PubMed]

8. Sully, E.K.; Geller, B.L. Antisense antimicrobial therapeutics. Curr. Opin. Microbiol. 2016, 33, 47-55. [CrossRef]

9. Good, L.; Stach, J.E.M. Synthetic RNA Silencing in Bacteria? Antimicrobial Discovery and Resistance Breaking. Front. Microbiol. 2011, 2, 185. [CrossRef]

10. Demidov, V.V.; Potaman, V.N.; Frank-Kamenetskil, M.; Egholm, M.; Buchard, O.; Sönnichsen, S.H.; Nlelsen, P.E. Stability of peptide nucleic acids in human serum and cellular extracts. Biochem. Pharmacol. 1994, 48, 1310-1313. [CrossRef]

11. Dryselius, R.; Aswasti, S.K.; Rajarao, G.K.; Nielsen, P.E.; Good, L. The Translation Start Codon Region Is Sensitive to Antisense PNA Inhibition in Escherichia coli. Oligonucleotides 2003, 13, 427-433. [CrossRef] [PubMed]

12. Japoni-Nejad, A.; Farshad, S.; Van Belkum, A.; Ghaznavi-Rad, E. Novel cassette array in a class 1 integron in clinical isolates of Acinetobacter baumannii from central Iran. Int. J. Med Microbiol. 2013, 303, 645-650. [CrossRef]

13. Ellington, M.J.; Kistler, J.J.; Livermore, D.M.; Woodford, N. Multiplex PCR for rapid detection of genes encoding acquired metallo- $\beta$-lactamases. J. Antimicrob. Chemother. 2006, 59, 321-322. [CrossRef]

14. Wayne, P.A.; CLSI. Performance Standards for Antimicrobial Susceptibility Testing, 13th ed.; CLSI Standard M02; Clinical and Laboratory Standards Institute: Wayne, PA, USA, 2018.

15. Kent, W.J. BLAT-The BLAST-Like Alignment Tool. Genome Res. 2002, 12, 656-664. [CrossRef] [PubMed]

16. Goltermann, L.; Yavari, N.; Zhang, M.; Ghosal, A.; Nielsen, P.E. PNA Length Restriction of Antibacterial Activity of Peptide-PNA Conjugates in Escherichia coli Through Effects of the Inner Membrane. Front. Microbiol. 2019, 10, 1032. [CrossRef] [PubMed]

17. Ghosal, A.; Nielsen, P.E. Potent Antibacterial Antisense Peptide-Peptide Nucleic Acid Conjugates Against Pseudomonas aeruginosa. Nucleic Acid Ther. 2012, 22, 323-334. [CrossRef]

18. Roth, B.L.; Poot, M.; Yue, S.T.; Millard, P.J. Bacterial viability and antibiotic susceptibility testing with SYTOX green nucleic acid stain. Appl. Environ. Microbiol. 1997, 63, 2421-2431. [CrossRef]

19. Schmittgen, T.D.; Livak, K.J. Analyzing real-time PCR data by the comparative CT method. Nat. Protoc. 2008, 3, 1101-1108. [CrossRef]

20. Hansen, A.M.; Bonke, G.; Larsen, C.J.; Yavari, N.; Nielsen, P.E.; Franzyk, H. Antibacterial Peptide Nucleic Acid-Antimicrobial Peptide (PNA-AMP) Conjugates: Antisense Targeting of Fatty Acid Biosynthesis. Bioconjugate Chem. 2016, 27, 863-867. [CrossRef] [PubMed]

21. Geller, B.L.; Marshall-Batty, K.; Schnell, F.J.; McKnight, M.M.; Iversen, P.L.; Greenberg, D.E. Gene-Silencing Antisense Oligomers Inhibit Acinetobacter Growth In Vitro and In Vivo. J. Infect. Dis. 2013, 208, 1553-1560. [CrossRef]

22. Ghosal, A.; Vitali, A.; Stach, J.E.; Nielsen, P.E. Role of SbmA in the Uptake of Peptide Nucleic Acid (PNA)-Peptide Conjugates in E. coli. ACS Chem. Biol. 2012, 8, 360-367. [CrossRef]

23. Mardle, C.E.; Shakespeare, T.J.; Butt, L.E.; Goddard, L.R.; Gowers, D.M.; Atkins, H.S.; Vincent, H.A.; Callaghan, A.J. A structural and biochemical comparison of Ribonuclease E homologues from pathogenic bacteria highlights species-specific properties. Sci. Rep. 2019, 9, 7952. [CrossRef]

24. Eidem, T.M.; Roux, C.M.; Dunman, P.M. RNA decay: A novel therapeutic target in bacteria. Wiley Interdiscip. Rev. RNA 2012, 3 , 443-454. [CrossRef]

25. Splith, K.; Neundorf, I. Antimicrobial peptides with cell-penetrating peptide properties and vice versa. Eur. Biophys. J. 2011, 40, 387-397. [CrossRef] [PubMed]

26. Martínez-Guitián, M.; Vázquez-Ucha, J.C.; Álvarez-Fraga, L.; Conde-Pérez, K.; Bou, G.; Poza, M.; Beceiro, A. Antisense inhibition of lpxB gene expression in Acinetobacter baumannii by peptide-PNA conjugates and synergy with colistin. J. Antimicrob. Chemother. 2020, 75, 51-59. [CrossRef] [PubMed]

27. Wang, H.; He, Y.; Xia, Y.; Wang, L.; Liang, S. Inhibition of gene expression and growth of multidrug-resistant Acinetobacter baumannii by antisense peptide nucleic acids. Mol. Biol. Rep. 2014, 41, 7535-7541. [CrossRef]

28. Rose, M.; Lapuebla, A.; Landman, D.; Quale, J. In Vitro and In Vivo Activity of a Novel Antisense Peptide Nucleic Acid Compound Against Multidrug-Resistant Acinetobacter baumannii. Microb. Drug Resist. 2019, 25, 961-965. [CrossRef]

29. Carpousis, A.J. The RNA Degradosome of Escherichia coli: An mRNA-Degrading Machine Assembled on RNase E. Annu. Rev. Microbiol. 2007, 61, 71-87. [CrossRef]

30. Greenberg, D.E.; Marshall-Batty, K.R.; Brinster, L.R.; Zarember, K.A.; Shaw, P.A.; Mellbye, B.L.; Iversen, P.L.; Holland, S.M.; Geller, B.L. Antisense Phosphorodiamidate Morpholino Oligomers Targeted to an Essential Gene Inhibit Burkholderia cepacia Complex. J. Infect. Dis. 2010, 201, 1822-1830. [CrossRef] 
31. Howard, J.J.; Sturge, C.R.; Moustafa, D.A.; Daly, S.M.; Marshall-Batty, K.R.; Felder, C.F.; Zamora, D.; Yabe-Gill, M.; Labandeira-Rey, M.; Bailey, S.M.; et al. Inhibition of Pseudomonas aeruginosa by Peptide-Conjugated Phosphorodiamidate Morpholino Oligomers. Antimicrob. Agents Chemother. 2017, 61. [CrossRef] [PubMed]

32. Barkowsky, G.; Lemster, A.-L.; Pappesch, R.; Jacob, A.; Krüger, S.; Schröder, A.; Kreikemeyer, B.; Patenge, N. Influence of Different Cell-Penetrating Peptides on the Antimicrobial Efficiency of PNAs in Streptococcus pyogenes. Mol. Ther. Nucleic Acids 2019, 18, 444-454. [CrossRef] [PubMed]

33. Yavari, N.; Goltermann, L.; Nielsen, P.E. Uptake, Stability, and Activity of Antisense Anti-acpP PNA-Peptide Conjugates in Escherichia coli and the Role of SbmA. ACS Chem. Biol. 2021, 16, 471-479. [CrossRef] [PubMed] 